\title{
TTR
}

Traduction, terminologie, rédaction

\section{Translation and Identity: Social Trajectories of the Translators of Hebrew Literature in French}

\section{Gisèle Sapiro}

Volume 26, numéro 2, 2e semestre 2013

Traduction et conscience sociale. Autour de la pensée de Daniel Simeoni

Translation as Social Conscience. Around the Work of Daniel Simeoni

URI : https://id.erudit.org/iderudit/1037132ar

DOI : https://doi.org/10.7202/1037132ar

Aller au sommaire du numéro

Éditeur(s)

Association canadienne de traductologie

ISSN

0835-8443 (imprimé)

1708-2188 (numérique)

Découvrir la revue

Citer cet article

Sapiro, G. (2013). Translation and Identity: Social Trajectories of the Translators of Hebrew Literature in French. TTR, 26(2), 59-82.

https://doi.org/10.7202/1037132ar

\section{Résumé de l'article}

Cet article traite de la relation entre traduction et identité à travers le cas des traducteurs et traductrices de la littérature hébraïque moderne en français. Sur la base d'une étude de leurs caractéristiques sociales et de leurs trajectoires, qui indiquent un double processus historique de spécialisation et de féminisation de cette population, il analyse les conditions d'acquisition des compétences linguistiques et sur les voies qui conduisent à la traduction. Les représentations qu'ils ou elles se font de leur activité de traduction, telle qu'elles ressortent d'une série d'entretiens approfondis réalisés avec les personnes concernées, sont mises en relation avec la trajectoire et l'habitus des traducteurs, suivant la proposition de Daniel Simeoni. Ceci permet de s'interroger sur le rôle que joue la traduction dans la construction de l'identité individuelle et collective. 


\title{
Translation and Identity: Social Trajectories of the Translators of Hebrew Literature in French ${ }^{1}$
}

\author{
Gisèle Sapiro \\ CNRS-EHESS \\ (Centre européen de sociologie et de science politique)
}

\begin{abstract}
This paper focuses on the relation between translation and identity through the case of translators from Modern Hebrew literature into French. The conditions of acquisition of linguistic skills and the paths that lead to the translational practice are analysed on the basis of a study of the social properties and trajectories of the translators, which reveals the population's double historical process of specialization and of femininization. The way translators represent their activity to themselves, as expressed during indepth interviews, is then placed in the context of the translators' trajectories and habitus, following Daniel Simeoni's suggestion. The question of translation's role in the construction of individual and collective identity is thereby raised.
\end{abstract}

Keywords: translation, sociology of translation, sociology of professions, identity, Modern Hebrew literature

\section{Résumé}

Cet article traite de la relation entre traduction et identité à travers le cas des traducteurs et traductrices de la littérature hébraïque moderne en français. Sur la base d'une étude de leurs caractéristiques sociales et de leurs trajectoires, qui indiquent un double processus historique de spécialisation et de féminisation de cette population, il analyse les conditions d'acquisition des compétences linguistiques et sur les voies qui conduisent à la traduction. Les représentations qu'ils ou elles se font de leur activité de traduction, telle qu'elles ressortent d'une série d'entretiens approfondis réalisés avec les personnes concernées, sont mises en relation avec la trajectoire et l'habitus des traducteurs, suivant la proposition de Daniel Simeoni. Ceci permet

1. A first draft of this paper was presented at the conference "Institutions, Habituses and Individuals: Social, Historical and Political Aspects of Cultural Exchanges", Tel-Aviv University, 2-5 May 2004. Thanks to Jill McCoy for her English editing help on this article. 
de s'interroger sur le rôle que joue la traduction dans la construction de l'identité individuelle et collective.

Mots-clés: traduction, sociologie de la traduction, sociologie des professions, identité, littérature hébraïque moderne

\section{Introduction}

As a social practice, translation can be studied at the level of its social conditions and at the level of translating practices. While historians (Espagne and Werner, 1990) and sociologists (Heilbron and Sapiro, 2002, 2008; Sapiro, 2008a, 2014) have been mainly interested in the first aspect, Translation Studies have focused on the second one, shedding light on the cultural normative constraints imposed by the target culture (Toury, 1995). Within Translation Studies, Daniel Simeoni (1998) suggested to switch the focus from the description of the norms of translation to the main agent of the cultural transfer, i.e. the translator. Translation is regarded in this perspective not as the result of a universal set of cognitive skills but as the product of social practices that depend on cultural norms internalized by the agents who act as translators. As a result of this change of focus, the (poly)systemic model (Even-Zohar, 1990) can be reframed using Bourdieu's field theory and his concept of habitus (Bourdieu, 1980, 1992, 1993). Such a reframing offers a bridge between Translation Studies and the sociological and historical approaches of translation, while focusing on the translator requires that translating practices be inscribed in the context of their social conditions. It raises new research questions such as: how does one become a translator? How is a translator's habitus shaped? How was this habitus transformed into a specialized habitus, i.e. a "translatorial habitus"? More specifically, under which conditions has a translator acquired his or her linguistic and translation skills? And what does the practice of translation owe to this habitus? How do this practice, the choices, and the decisions that translators make conform or not to the rules, norms and or conventions of their field(s) of action (the publishing field, the literary field, the academic field and its subfields: philosophy, sociology, history, and so on)?

Among the agents involved in the chain of cooperation by which a text circulates from one language to another, translators occupy a key position along with publishers, editors, literary 
agents, state officials, booksellers, and critics. As has been observed (Venuti, 1995; Prunč, 2007), the great value of work translators do contrasts with the low status they are accorded in many places. Translation has been for centuries an intellectual activity among others, such as commentary or criticism. Although it underwent a professionalization process, translation is still not fully professionalized and is often done for free, as a "calling" or as a "hobby", for example in the case of poetry translation.

The study of translators as an occupational group has recently emerged as a research field. It includes the study of translators' social background, their struggles for professional status, their professional identity and self-image (Sela-Sheffy, 2005; SelaSheffy and Shlesinger, 2011). As Sela-Sheffy and Shlesinger (2011, pp. 2-3) put it: "Their insecure status as a profession is especially paradoxical today, as so much attention is being devoted to cross-cultural processes such as globalization, migration and trans-nationalism." The propensity to endorse subservience to the dominant cultural norms, which characterizes the Western translational habitus (Simeoni, 1998, pp. 12-13), can be related to this insecure status and more broadly to the marginal position of translators in the fields of cultural production, compared to the central position of cultural producers.

In this paper, I will focus on the social trajectories of translators from Modern Hebrew to French, and more specifically on the relation between translation and identity. The broader questions that underpin this research are: under which conditions are translators' linguistic and translating skills acquired? How do the translators represent the practice of translation to themselves? How is this representation related to their habitus and trajectories? What role does translation play in the construction of individual and collective identities? Though the present case study is limited in scope, it paves the way for further research directions on these issues.

Language is a central component of social and cultural identity. It conveys social and cultural representations, as well as principles of division of the world. Native language is part of the primary habitus, as defined by Pierre Bourdieu (1980), and includes the corporeal habitus, illustrated by one's accent. Linguistic skills can also, under certain conditions, be a resource, a specific kind of cultural capital, which may be invested in international cultural 
exchanges, and more specifically in translation. These two aspects of language: that is, as part of social and cultural identity and as (potential) cultural capital, are not contradictory. They can, on the contrary, be tightly embedded, as we will see upon examining the translators' trajectories and practices. Moreover, they both take part in the process of constructing collective identity.

The role of culture in the building of national identities is now well established (Even-Zohar, 1990b; Thiesse, 1998). More broadly, literature has been a means to claim social or cultural identity (Even-Zohar, 1990a; Thiesse, 1991; Serry, 2001): territorial (national, supranational, regional), religious (Catholic, Jewish), social (proletarian), gendered (women's literature). Such claims are often conveyed by intellectuals who, dominated in the literary field, become spokespeople for the dominated group they come from or join (as in the case of religious conversion) as a way to exist in the field and to reach a specific public within the book market. The role of these intellectuals is central in creating the demand for cultural products related to the affirmation of a collective identity. In a similar way, the importers of a dominated culture into a dominant one help create demand for these products, as appears in the case under study here.

The number of translations of Modern Hebrew literature into French has significantly increased since the end of the 1980s. While in the years 1980-1987 the average number of books translated every year was 5.5, it grew to 11.1 from 1988 to 1997 (Sapiro, 2002). With regards to the number of literary books translated from Hebrew overall, French held the third position, after English and German. The rise in the number of literary translations from Hebrew into French since the end of the 1980s can be partly explained by the context of globalisation, though such an increase is not a mechanical reflection of these conditions. During the era of globalization, international cultural exchanges increased and the world book market became more unified. This context created the conditions which favored the investment of various agents in the "exportation" and "importation" of Hebrew literature, including state agencies such as the Institute for the Translation of Hebrew Literature, literary agents, series editors, and translators (Sapiro, 2002; 2008b; 2008c). The present paper will focus on the role of translators in the cultural transfer and on the way they represent this role to themselves. 
This study is based on a quantitative analysis of the 269 literary books translated from Modern Hebrew into French from 1945 to 2002 (the database compiled for this study included the name and gender of the translator, the publisher and date of publication, and other variables) and on in-depth interviews I conducted between 2002 and 2005 with translators from Hebrew into French (11), publishers, editors and literary agents involved in the importation of Hebrew literature (9). Two of the translators were or had also been editors of a series of Hebrew literature. The population interviewed includes 7 out of the 8 translators who published at least 5 translations from Modern Hebrew into French from 1985 to 2002, and 3 out of the 10 who translated between 2 and 4 titles, so it is representative of the small core of translators who concentrate the highest number of translations from Hebrew into French during the period of significant translation activity growth. The remaining translator has trained many other, younger translators. There are 3 men and 8 women, belonging to different generations. Two of them are Catholic, all the others are Jewish. In addition to these eleven translators, the author of this paper represents the population of occasional translators who translated only one title during the period.

As noted by Simeoni (1998, p. 31), "modern sociographies of single translators' professional trajectories are sorely lacking. The present void could be filled out by means of simple interviews, without resorting to the heavy apparatus of samplebased techniques." We could add that interviews provide rich qualitative data for reconstructing translators' social trajectories, their representations of their activity as translators and the role that their translation activity plays in building their identity. This is data that no questionnaire could obtain, and it is generally not available elsewhere (in contradistinction to other populations of cultural producers such as writers, for whom there often are many public biographical sources such as memoirs, interviews, and correspondence, in addition to the numerous traces of their work such as manuscripts, projects and notes organized and classified as archives).

The interviews with translators included four sets of questions. The first set dealt with the translators' trajectories and relation to Hebrew literature and culture: how did they begin translating Hebrew literature? What does translating mean to them? Is 
translation an occupation for them? A mere source of income? How did they discover Hebrew literature? Do they travel often to Israel? A second set of questions had to do with their relationships with publishers: which publishers do they work with? How did they get in touch with them? Do they propose the texts they translate? When they do, what arguments do they put forward to convince the publishers? What obstacles do they encounter? Are they in contact with the private and public literary agents? Are they in contact with the author during the translation process? The third set of questions focused on the process of translation itself: How do the translators work? What is important for them to transmit? Have they experienced differences when translating various literary genres? The last set of questions focused on book promotion and reception: were they involved in these phases? How did they feel about the reception of the books they had translated, and about the reception of Hebrew literature more broadly? By the end of the interview, the translators were also asked about the way they conceived the relationship between Hebrew literature and Jewish culture. In the present paper, I will focus on the answers to the first and last sets of questions. ${ }^{2}$

The article is organized into six sections. Through a comprehensive study of the population of literary translators from Hebrew into French, the paper will first analyze the social conditions which favor access to the activity of translating Hebrew literature (1). The evolution of the social recruitment of translators from Hebrew and the transformations of translation as an activity reflect a broader process of specialisation and professionalization of literary translation, even though the occupation requires no formal conditions such as a diploma, and no standard apprenticeship or specific training (in contradistinction to interpretation and technical translation). Translation, however, appears seldom to be the first career choice of translators of Modern Hebrew literature into French (2). Two paths for acquiring linguistic skills were identified: training and emigration (3). Professionalization coincided with a feminization process (4). The relation between these two processes is partly explained by work conditions. But

2. In most cases, the interview extracts and trajectories are kept anonymous out of respect for confidentiality and because the focus here is on the translators' trajectories from a sociological perspective. As such, identification is not necessary. 
the choice of literary translation as a hobby or as an occupation cannot be reduced to "rational choice", it is often experienced as a "calling" or as closely related to other literary aspirations (5), and it is often deeply connected to cultural identity (6).

\section{The specialization of literary translators from Hebrew to French}

The process of specialisation in the translation of Modern Hebrew literature occurred in the 1980s, parallel way to the development of this literature, although with a ten-year lag. Two types of evidence may be used to identify this process. First, before 1980, one title out of four was indirectly translated from a language other than Hebrew (primarily English, but also German and Italian), whereas from 1982 to 1992, only one title out of ten originated in a foreign language. The second factor is the increasing concentration of translations in the hands of a small group of translators. ${ }^{3}$ The ten translators who translated more than one book before 1981 account for one-third of the overall translation output during the period ( 31 out of 89 books translated), while in the next decade, the eleven translators in the same case account for two-thirds of the total output (53 out of 80 books translated). It should also be specified that among the twenty-four translators who translated one book during the first period, only four translated another one in the next period. Among the ten major translators of the first period, four belonged to the export channel, which means they worked for the World Zionist Organisation, its executive arm, the Jewish Agency, or the department of Education and Culture in the Diaspora, which was in charge of translations of children's books. For the six other translators, translation was a secondary activity besides their main occupation, a kind of hobby. They translated books by a single author, while their homologues of the next period all translated at least two different authors. Significantly, the translator of an author who became famous in the 1970s thanks to the translation of his work into French, winning the most important literary prize for foreign literature in France, the Medicis prize, told me in an interview that she had never been a

3. The whole population of translators from Hebrew literature includes 124 individuals (in 18 cases, the name of the translator is missing). Most of these 124 translated only one book, alone or in collaboration with another translator. 
"translator" (though she had translated 14 books and was awarded a translation prize!): she said she was not a "real translator" because she was "capable" of translating only what she liked. She meant she was not a professional translator. On the contrary, among the translators of the 1980s, one of them translated more than 24 titles by 16 different authors whom she often promoted on the French market, and she has become the editor of a series of Modern Hebrew literature; another translated at least 17 books by 9 authors, and a younger translator, 12 books by 7 different authors. This specialization also implied a professionalization process, though most of the translators, even in the second period, came to translation by chance.

\section{Becoming a translator}

In contradistinction to technical translators, literary translators have seldom gone through academic training in translation. Their access to translation is based on linguistic skills and cultural capital, especially literary capital. There are two idealtypical ${ }^{4}$ paths for becoming a translator of Modern Hebrew literature to French: linguistic training in Hebrew, or migration paired with literary studies.

Although it trains Hebrew teachers, the Institut national des langues et civilisations orientales or INALCO (previously called the École des langues Orientales or Langues O), which provides linguistic training at the highest level, can also be considered as the most specialized path to translation from Hebrew in France. It is also the oldest: the department of Hebrew was created in 1936. Between 15 and 25 students attended INALCO in the 1950s, and enrollment went up to 80 in 1968. As one of the translators who completed a degree there at the end of the 1950s puts it:

Mais les Langues orientales de l'époque, c'était pas les Langues orientales d'aujourd'hui. A l'époque il y avait 25 élèves en première année dont 15 bonnes sœurs, dix protestants et deux juifs. Voilà. Et le répétiteur à côté du professeur Horowitz, s'appelait René Samuel Sirate, à l'époque, qui était aumônier de la jeunesse au Consistoire de Paris. C'était les Langues Orientales de l'époque. Voilà.

4. Following sociologist Max Weber's method of constructing "idealtypes" based on the most typical traits of one or more phenomena. 
The choice to learn Hebrew was in most cases motivated by a religious interest rather than by plans to pursue a professional project relating to the language. It is worth noting that religious Jewish students attend religious seminaries called Yeshiva, and not secular schools. The Hebrew classes at Langues $\mathrm{O}$ therefore attracted mainly Christians who had a religious interest in learning the language. In the 1980s, the rate of Jewish students increased, but there were still 30\% non-Jews, which seems no longer to be the case. This training became much more professional after Langues $\mathrm{O}$ became affiliated with the Sorbonne (University of Paris III) in 1971. Even before then, however, it was a very specialized training that provided students with rare skills they could use on the French job market. Mireille Hadas-Lebel, an alumna, who was trained in classical humanities (Latin and Greek) in the French elite higher education school École normale supérieure, and who passed the very competitive Agrégation examination for high school teachers, was called to teach at Langues $\mathrm{O}$ a few years after she achieved her degree in Hebrew; at the time she was a teacher of French and Latin at a high school in Strasbourg, where she could continue her Hebrew studies at the University while preparing a $\mathrm{PhD}$ in classical literature. She became an important professor of Hebrew studies, training many of the future French-to-Hebrew translators, and she was later recruited at the Sorbonne as full professor.

The Hebrew language as a rare resource can also be illustrated through the trajectory of another translator I interviewed, a Catholic woman who wanted, in the 1960s, to become a librarian at the French National Library (BNF), but who was too old to apply for the competitive State examination. She recalls being told by the head of her department:

"Vous devriez apprendre une langue, à la $\mathrm{B}$ [ibliothèque] $\mathrm{N}$ [ationale] en ce moment il ny a personne pour le roumain, apprenez donc le roumain et ça vous permettra de mener une carrière normale." Je lui dis: "Le roumain, ça ne m'intéresse pas, je voudrais apprendre l'hébreu."

She then earned a degree in Hebrew at the École des Langues Orientales and became a librarian in the Hebrew manuscripts department at the National Library, where she worked all her life. During her training, she wrote a dissertation on a contemporary 
Israeli writer, David Shahar, and met him when he came to Paris. She then decided to try and translate two of Shahar's short stories and proposed them to a literary magazine. She proposed one to the Nouvelles litteraires, where it was published, and the second to Gallimard's review, the Nouvelle Revue française. One of the editors at Gallimard, Dominique Aury, found it interesting and suggested that she continue translating other short stories. She did so without a publishing contract, and Gallimard, the most prestigious French publisher, accepted the collection as a book. By that time Hebrew literature was still almost completely unknown in France, and Shahar had not even been translated into English. The translator, Madeleine Neige, then went on translating Shahar's entire body of work into French (14 books), all the while keeping her main job as a librarian at the National Library.

Since there were few translators from Hebrew to French, and since most of them translated a very small number of books, one could become a translator at any age. An interesting case is that of a friend of Madeleine Neige. This translator, also a Catholic woman, had studied Latin and Greek in high school and earned a degree in History, but abandoned her training in order to raise her children. Her husband was the head of the manuscripts department at the National Library, and had contacts with Israeli scholars who invited him to Israel. She had always helped her husband with his work and thought it would be interesting to learn a Semitic language such as Hebrew, given that she already knew Latin and Greek. Since childhood, she had been fascinated by the Hebrew language, the nuns at school having forbidden their pupils to read the Bible in Hebrew out of fear they would lose their faith. She therefore obtained a degree in Hebrew in the 1980s, when she was already over 50 years old. As she prepared a dissertation on the Israeli writer Aharon Appelfeld, she was recommended by her friend, the previous translator mentioned, to a publisher who happened to be looking for a translator for Appelfeld's work. By that time, publishers had become interested in Hebrew literature, and there were still not many translators. Arlette Pierrot then specialized in the translation of Hebrew literature, sometimes working in collaboration with Israeli scholar Ziva Avran. Before the year 2001, Pierrot had translated around 15 books. 
At the same time, Hebrew training programs also developed in the universities. By the end of the period under study, three Universities were offering full graduate courses in Hebrew Studies: the universities were Strasbourg I (where the department was founded in 1955), Paris VIII, and Lyon III. In the 1970s, two competitive examinations for teachers of Hebrew in high schools were created: the CAPES in 1973 and the Agrégation in 1977. They were initiated by Rabbi Sirat, who was in charge, beginning in 1972, of the "Inspection générale de l'hébreu," and who in 1980 would become the "Grand Rabbin de France" (see RenéSamuel Sirat: "Envers et contre tout, prêcher en faveur de la paix" (interview), L'Arche, n' 544-545, June-July 2003). The demand for Hebrew instruction increased in the 1980s. In 1995-1996, there were 5,747 pupils in public high schools learning Hebrew, and 6,521 in 2002-2003 (L'enseignement des langues étrangères en France, Senate information report). However, the appeal of rare languages decreased in the 1990s. When the Hebrew Agrégation examination was created, there were two positions offered every year, but later it was restricted to one, and by the end of the period under study there was only one position open every two years, since there were enough young teachers and not a sufficiently large demand.

Some of the younger translators are Hebrew teachers with the CAPES or the Agrégation certificates. One of them, raised in Morocco, went to Israel in 1972-1973 with a scholarship in order to study International Relations. She then returned to France in 1973, failed the competitive examination for studying at the École nationale de Science politique, and switched her focus to Hebrew and the classical humanities. She earned a degree at INALCO and passed the CAPES examination. She became a Hebrew teacher while continuing graduate studies in classical humanities with a particular focus on Greek. She did some translation for the Israeli Embassy and wrote papers for a Jewish journal. In the mid1980s, she was recommended by the Israeli cultural attaché to a publisher who wanted to translate a novel by a renowned Modern Hebrew writer. She began translating and, once it became clear to her that she would not be able to get a university job, abandoned academic training. But she kept working as a Hebrew teacher until 1997. She then went on leave in order to prepare the "Agrégation interne" (internal competition for teachers who have already 
earned the CAPES) and became pregnant. In 1998 she stopped teaching and has been working full-time in translation ever since. Thus translation appears here as a second career chosen only after the initial ambitions of an academic career were abandoned.

The second idealtypical path for becoming a translator of Hebrew is not founded on a specialized training but on the use of linguistic resources and cultural capital in a process of professional reconversion, often linked to emigration. Most of the translators whose trajectories correspond to this type were born in France and emigrated, for Zionist reasons, to Israel where they stayed for a few years. Most of them earned at least a Master's degree, either in French Literature or in Comparative Literature, in some case coupled with a degree in Philosophy. In Israel, they taught French or French Literature at the University. When they returned to France, their skills in French or in French literature were no longer a rare resource on the French academic market as they had been in Israel. But the Hebrew language they had learned while living in Israel turned out to be a rare resource in the 1980s French publishing field in the context of the growing demand for Hebrew translations. They thus began translating Hebrew literature although it was not their specialty - they all emphasized this point in the interviews-, investing their broader literary knowledge in their translation work. For all of them, this was also a means to maintain contact with Israel and Hebrew culture. Despite the fact that they were not well integrated in Israeli society and felt nostalgically for France, they still considered the Hebrew language as part of their identity. Translating was for them a way to remain in Israel once they had left (I shall return to this point). Most of them did not obtain their $\mathrm{PhD}$ and abandoned an academic career, busy instead with earning a living by translating (the rare translators who earned their PhD took the opposite path, abandoning translation for an academic career). This group of emigrants also includes individuals with artistic ambitions. For them, translating is or was initially an occupation that allowed them to earn a living once they returned to France until they could become recognized as a writer or a playwright (see below).

\section{The feminization process}

The professionalization process went together with the feminization of the population of translators. In the 1980s, there 
was a reversal of the sex ratio among the translators of Hebrew literature into French: before 1981, 37 titles out of 90 were translated by women ${ }^{5}$ ( 5 of which in collaboration with men), and from 1982 to 1993 the number rose to 46 out of 80 (4 titles were translated in collaboration with men). But the real feminization process occurred in the 1990s. This process can be observed among the authors as well as among the translators. Among the 19 female Israeli authors who were translated into French before 2002 (out of 104 writers, these female authors represent $16 \%$ of the whole), 13 were translated between 1993 and 2001, which represents one-third of the writers translated during this period. This rate reflects the representation of female authors in the catalogue of the Institute for translation of Modern Hebrew literature for the year 1999-2000, but it is inferior to their place in the 2001 catalogue put out by literary agent Deborah Harris (Harris is the most prominent private agent currently selling foreign rights to works of Israeli authors), which presents 7 women out of 12 authors of fiction.

The feminisation process can also be observed among the translators: from 1993 to 2001, 70 out of 99 books of Hebrew literature were translated by women, i.e. more than two thirds, against one half during the previous decade. The concentration of about two thirds of the titles published (60) in the hands of 10 of these 20 female translators (against 14 male translators, and 5 unknown), most of whom began translating in the 1980s, provides evidence for the specialization and professionalization process. Five of them translated between 12 and 20 titles published before 2001 (and some other titles that were unpublished at the time). It is notable that while male authors are translated about fifty percent of the time by male and female translators, female authors are more often translated by women: out of a total of 35 books by female authors translated into French, only 6 were translated by men.

5. If we consider only direct translation from Hebrew, there were already, before 1982, fewer books translated by men than by women: 25 against 30 , the reversal of the ratio being due to the other languages (17 against 6). Nevertheless, the gap between men and women widened in the next period: 29 books translated by men against 42 by women, while it shrunk in the other languages (4 against 3 ). 


\section{Work conditions}

The feminization process is also related to the precariousness of the work conditions. As one of the translators put it:

Alors, franchement, c'est vraiment pas étonnant qu'il y ait des femmes, c'est vrai c'est comme dans l'enseignement, c'est pareil les salaires ne suivent pas, et si tu ne travailles pas à temps plein tu n'arrives pas à finir dans les temps, en plus si tu es en retard, si tu es prise sur une traduction, ça c'est le gros problème, tu ne peux pas t'engager sur une autre et si tu dis non une fois, deux fois, léditeur il ne viendra plus te chercher.

Translation has never been a well-paid job, and it is difficult to earn a living entirely from it. For none of the male translators in our population was translation the main occupation. A translator who fits both profiles-he studied Hebrew at Langues $\mathrm{O}$ and earned a Master of Arts degree in French at Tel-Aviv University before returning to France, where he began a career working in Jewish Community organizations-defined translation as a hobby more than a professional activity. He explained:

c'est comme ça, tout à fait par hasard, que je suis entré dans cette activité qui n'a jamais représenté pour moi autre chose qu'une activité, je dirais de hobby, d'un violon d'Ingres, pas une activité professionnelle... parce que vous savez que c'est très mal payé. On n'en vit pas ou alors il faut traduire très vite et assez mal, pour pouvoir en vivre.

He then calculated that he was less paid than a cleaning woman.

The lack of social recognition for people choosing translation as an occupation can also be observed in the invisibility of the translator (Venuti, 1995): required to disappear behind the author's style, the translator has had to be invisible as a person in order to successfully carry out the task of translation, to be "completely transparent, odourless, tasteless," as one of the translators put it, "le style du traducteur, du meilleur traducteur, c'est celui qui est complètement transparent, inodore, sans saveur"; as a result, translators have also remained socially invisible, except for famous writers whose translations became part of their work (like Baudelaire's translations of Edgar Allan Poe): their names were not always mentioned on the covers of the books they translated, they were not informed by publishers of the success of their books, 
and were not typically invited to events related (for example, the translator of Amos Oz's novel Black Box, which was granted the 1988 Femina Prize, was not invited to the awards ceremony); in the media, the name of the translator was seldom mentioned and the translation itself almost never discussed.

This situation has changed as a result of the claims and struggles of literary translators in France, who in 1973 created their own professional association (ATLF), separate from that of the technical translators (Société française de traduction, founded in 1947) (Heinich, 1984). The wages were increased in the 1990s, and at least for upmarket literature the name of the translator now appears on the cover and is usually mentioned in newspaper reviews. Translators are more often invited by publishers to take part in promotional events. But the conditions are still very precarious, and the translator "controls nothing," as one of them put it. A text can be completely rewritten by a "rewriter" who does not know the original language, and the translator cannot voice her opinion in the matter. It is also noteworthy that, apart from those who aspire to become editors and have the resources to do so, most translators seldom propose the books they translate. Professional translators cannot even choose what they translate. It often happens that when they are offered an interesting piece to translate, they are busy with another book, so they cannot accept. For the same reason, they are sometimes unable to pursue multiple translations by the same author: the publisher wants the work to be translated immediately despite the fact that the book may not be published for several years. Competition and rivalry between translators is harsh, and, in an occupation where work conditions are already atomized and individualized, it seems as though publishers threaten to destroy any solidarity that might exist among them.

All of these characteristics of translation as a social activity contribute to its being suitable for the female habitus, of which social invisibility and working at home are a part. This is all the more true if a female translator has children to raise: working at home and organizing one's own time are the material conditions that make the precarious conditions more acceptable. Some of them have completely internalized this social invisibility as part of their feminine condition, and as a result they feel comfortable with it as translators. For example, one female translator, already mentioned, who denied being a professional translator despite 
having translated 14 books and winning a prestigious translation prize, said that for her, the prize was an award to the author. The translators, however, would certainly not accept these conditions were there no symbolic profits associated with their activity. Such symbolic profits can be of great value, as we observed in the case of a Hebrew teacher who, despite earning a good salary, renounced her job in order to pursue translation.

\section{Calling}

The hard conditions and inherent difficulties of the activity of translating as a social and cultural practice are experienced as bearable when translation is considered either as a hobby, a temporary occupation, or a calling (Kalinowski, 2002). Translators often emphasize the ascetic character of the daily practice of translation. They describe their work on the text as a "physical" effort, "hard", and they use the metaphor of sweat. For them it is "Sisyphean work" in the sense that you're always beginning anew", a kind of "forced labour" ("un travail de forçat"). Some use the metaphor of "battle," a "battle for each word", a "fight body against body" ("bagarre du corps à corps"). One of them explained: "C'està-dire que je me bats comme un sculpteur se bat avec la pierre ou avec la matière parce que la matière résiste!" The metaphor of the work in translation as "a baby you have to feed," in one translator's words, is another expression of the corporal dimension of translation.

For professional translators, this struggle with the text is a real source of suffering when they do not appreciate the piece they have to translate. The translator has then to face a dilemma: either she takes liberties to improve the original text, or she remains faithful, reproducing its flaws. In the second case, the translator risks being held liable for the text's flaws. Yet the suffering is rewarded when the original text is beautiful in their opinion.

The way translators represent their work to themselves varies according to two factors: first, professional as opposed to non professional activity of translation (the latter meaning here that translation is not the primary source of income because it is, for example, a secondary occupation); second, a translator's personal aspirations, or absence thereof, in another activity of intellectual or cultural production. While, as we have seen, professional translators cannot choose the books they translate and often have 
a disenchanted representation of their work, the discourse of passion, love and calling is much more present in the "amateur" group. As one of the translators put it: "si on n'a pas vraiment une passion pour la traduction, on ne tient pas très longtemps, parce que c'est pas la chose la plus rémunérée au monde." However, such a representation can also be found in the first group, in the case of a translator who invested all her life and time in translation, an activity she sees as a mission (I will develop this point below): “C'est un métier (comme l'écriture est un métier... c'est un métier... c'est de l'artisanat. Mais c'est beaucoup plus quelque chose qui a trait à ma vie, à ma survie, à mon être le plus profond. Je peux pas faire autre chose!" But she also has ambitions to study translation from a theoretical standpoint.

Considering the second factor, we observe that in the eyes of those who make a major investment in translation, "translating is writing." On the contrary, those who have personal intellectual or literary ambitions - mainly writers-conceive of translation not as a "calling," a "mission," or their "life's work," but as an exercise feeding their own literary work ("un combustible"), a "school of writing." Whereas translating gives the first group existence through writing, for the second, translating is an experience of "disappearance":

quand je me plonge dans une traduction, quand je... m'immerge en fait dans une traduction, je fais l'expérience, disons, de presque... enfin, de la disparition ou de l'anéantissement positif, c'est-à-dire... de la fusion, quoi, tu vois, voilà. Lexpérience mystique de la..., comme disent les Hassidim, du "Bitoul Ha Yesh" [néantisation de l'être], l'extinction du moi, tu vois, la... la suppression du moi. Et ça c'est très intéressant, c'est une expérience pour un écrivain qui est très intéressante. Parce qu'on est tellement écrasé par son moi quand on écrit, quand on est, j'sais pas, artiste en général, que cette dissolution, tu vois, peut produire des effets tout à fait passionnants, vertigineux, intéressants, etc. Le fait de, voilà... En fait, tu deviens un autre.

This experience, also described as "dispossession" or "depersonalisation,"enriches in turn the personality of the translator as an author, all the more so when the translator is working on the text of a great writer: translating is then experienced as a kind of intellectual exchange with the writer. 
The propensity to be a "source" or a "target" translator, that is, respectively, tending to remain faithful to the original text or tending to adapt it more freely to the target culture (Toury, 1995), seems also to vary according to those factors, although not systematically. Translators with literary ambitions feel less respectful of the original text. They insist that what is important is the "music" and not the "words" or semantics: it is more important to be faithful to the "music." This is also the case with some of the professional translators, who have internalized the publishing norms of the target culture and of the local publishing field. Some of them change, for example, the names of the protagonists, with the author's approval, in order to make it easier for the reader to know whether certain characters are male or female. On the contrary, amateur or occasional translators try to be as "faithful" as possible to the original text.

\section{Cultural identity}

Interest in Hebrew, which leads these individuals to acquire the requisite linguistic skills in this language, is not due to its centrality (De Swaan, 1993, 2001), nor to tradition (although Jewish boys learn some biblical Hebrew for their Bar-Mitzvah, they don't go on to use it as a living language), but rather to its value as cultural capital. It fits Max Weber's idealtype of rationality with regards to values (Weber, 1995, pp. 55-56), rather than rationality towards an end or traditional action. In France, Hebrew is a rare language with religious connotations as the language of the Bible, and is categorized among the classical languages. Apart from erudite specialization, learning Hebrew in France is very often linked to a quest for cultural identity.

For the Jewish translators, who represent the vast majority of the population considered in this study, learning Hebrew is always linked to Zionism and to the quest for Jewish identity, particularly when this identity is not defined as religious, but as cultural (national). One of the translators recalled that when he was in high school, he wanted to learn a foreign language; he hesitated at first between Chinese and Hebrew, but finally found Hebrew to be much easier. He then added: "ça coulait plutôt de source puisque je viens d'une famille juive même si pas toute ma famille est juive..." He explained later: "J'étais pas dans une famille religieuse! Ben, c'est-à-dire que j'étais dans une famille 
où la question du judaïsme était liée à l'identité mais pas plus que ça... pas au sens religieux du terme."

Language is also what is left when the fulfillment of the Zionist dream-emigration to Israel-ends with a return to France. Aside from the capitalization of linguistic skills, often associated with a professional reconversion as we have seen, translating Hebrew literature is "a way to stay." It is a way to maintain contact with Israel and eventually transmit Hebrew culture to one's children. Thus translation appears as a means to bridge two cultural identities which form a "cleft habitus" (Bourdieu, 2013, pp. 454-455), typical of cultural and religious minorities (although Bourdieu does not use the term in this particular context, it is a perfect fit for these cases).

However, the relation between native French culture and chosen Hebrew culture is very complex and varies according to individual habitus and experience. For example, one of the translators, born in Turkey, was raised in a family who was fascinated with French culture. She fulfilled the familial dream and immigrated to France at age 20, but had a very disappointing experience. She then travelled to Israel and discovered Zionism and Hebrew. In Israel, she found the utopia she was seeking-she became a specialist in 17th century utopia-, and transposed to Hebrew culture all that her family had invested in French culture, in an attempt to revive the memory of this forgotten familial culture. She married a French man who did not adapt to life in Israel-they lived for a few years in the Negev-and they ended up returning to France together. Her reconversion to translating Modern Hebrew literature, which was also linked to professional reasons, was a way to endorse her cultural identity and became for her a mission, a militant endeavour.

For other translators, leaving France provoked feelings of great nostalgia for French language and culture. Translation was a means to return home and renew the contact with French culture and the intellectual milieu, particularly for those who had left young and had no academic or professional experience in France. It became a way to mediate between the two cultures without being conceived of as a mission.

In certain cases, the emigration experience to Israel was negative and very painful. The quest for Jewish identity collided 
with severe cultural shock, and expectations were far from met. One of the translators, whose grand-parents died in the Shoah, told us that for her, Hebrew literature was totally foreign to Jewish identity:

Enfin, moi ça me pose problème parce que, je vais te dire, je suis montée en Israël tout feu tout flamme, persuadée de m'exploser... enfin de trouver vraiment mon identité... j'ai eu vraiment le contraire! Je suis partie d'Israël avec une énorme colère au fond de moi-même! Qui s'est calmée, maintenant ça va beaucoup mieux, mais j'étais en rage quand je suis partie, parce que j'estimais qu'on m'avait volé de quelque chose, si tu veux, de mon idéal... de ce que c'était que le peuple juif quoi, en fait! Et du coup là... j'ai eu très très mal, maintenant ça s'est calmé, mais bon... et automatiquement, c'est vrai que la culture israélienne, pour moi, m'est complètement étrangère. Donc la littérature de tous ces sabras... [...] Je veux dire, je n'ai jamais pu me sentir chez moi en Israël, voilà! Tu sais quoi, voilà! Donc je ne vais pas me sentir chez moi, chez des auteurs qui sont Israéliens. Je me sentirais chez moi chez les auteurs qui parlent de la fracture, de l'immigration, de celui d'être étranger, tout ça, oui... ça c'est mon identité juive, à moi! Le bel Israélien, fier, dominateur, tout ça... Non! [Authors' note: note the possibly unconscious reference to de Gaulle's infamous phrase on Israel]

Finally, the cultural and social identity of the translator is involved in her literary tastes and preferences. Translators who are not very familiar with Israeli culture and contemporary Hebrew literature prefer writers like Appelfeld, who was not born in Israel and is much closer to the European and/or Jewish diasporic culture of the translators. Not surprisingly, Appelfeld is one of the authors taught at the Langues $\mathrm{O}$, where his translators discovered him. To more contemporary authors, they prefer mainstream authors such as $\mathrm{Amos} \mathrm{Oz}$, who write in a classical language closer to the academic language they learned. But a woman translator can also feel close to younger female authors whose novels deal with feminine experience. Translators more familiar with Israeli culture, and particularly those who work closely with the Institute for the Translation of Hebrew literature, try on the contrary to get information about new trends in Hebrew literature and contemporary Israeli literary tastes. Translators in this group 
imported authors such as Yaakov Shabtaï or younger, more avantgarde figures such as Orly Castel-Bloom and Etgar Keret. An author like Yoram Kaniuk, who addresses subjects such as the collective identity of the Jewish people, relations between the Jewish people and Israel, and moral dilemmas, all with a crude realism enhanced by fantastic or grotesque devices, appeals more to translators with "torn identities."

\section{Conclusion}

Studying a group of literary translators working from a specific language can help us not only to understand the intensification of literary exchanges between two cultures, but also the principles of selection of cultural products that are imported and the norms of translation they apply. Access to literary translation is not controlled by formal training or by the possession of a title, but since translation always requires linguistic skills, the first question is whether such skills derive from inherited capital or, if not, how were these linguistic skills acquired? This case-study suggests that there are two idealtypical paths for acquiring these skills: regular training and specialization, or emigration.

Becoming a translator also requires an inherited and/or acquired cultural capital in the specific field considered, here literature. Inherited cultural capital, which is part of the habitus, shapes cultural identity and helps explain the appeal that the Hebrew language exerted on the future translators of Modern Hebrew literature. But the mastery of language becomes in itself a cultural resource or capital that can be converted on the target cultural market. The status of the language in the target culture, its prevalence, centrality and cultural or religious value, and its availability in school curricula (i.e. the educational supply), especially for peripheral rare languages (Heilbron, 1999; Branchadell and West Lovell, 2005), are among elements that determine the conditions of the importation. Further research should also examine the role of social capital in the source or target intellectual field as a condition for becoming a translator.

The way translators carry out their work depends on their degree of professionalization, the work conditions in the target publishing field, their ability to choose and to propose translations, the space left open for negotiation with publishers, the cultural norms that guide their practice and their ability to 
distance themselves from these norms. Finally, the translator's way of working is also linked to his or her social trajectories and experiences in the source and target cultures, as well as relations between the two. Translation appears indeed to be more than a mere occupation or profession: it is invested with creative aspirations (as an exercise for creative writing or as creative writing in itself) and with cultural values that shape the individual's identity and help her bridge a cleft habitus which, as we have seen, results from belonging to a cultural minority. This case study thus illustrates the fruitfulness of Daniel Simeoni's invitation to focus on "the translator's habitus as a locus of tension revealing an extreme yet very representative configuration of intercultural, as well as global influences" (Simeoni, 1998, p. 21). Further research should try and connect the stylistic choices and decisions translators make (lexical, rhetorical and matricial) to their habitus and social trajectories, and should compare translators' discourse on their work with their actual translation practices.

\section{References}

Branchadell, Albert and Margaret West Lovell, eds. (2005). Less Translated Languages. Amsterdam/Philadelphia, John Benjamins. Bourdieu, Pierre (1980). Le Sens pratique. Paris, Minuit.

Bourdieu, Pierre (1992). Les Règles de l'art. Genèse et structure du champ littéraire. Paris, Seuil.

Bourdieu, Pierre (1993). The Field of Cultural Production: Essays on Art and Literature. In R. Johnson, ed. Cambridge (UK), Polity Press.

Bourdieu, Pierre (2013). Manet. Une révolution symbolique. Paris, Seuil/ Raisons d'agir.

Casanova, Pascale (2002). "Consécration et accumulation de capital littéraire. La traduction comme échange inégal." Actes de la recherche en sciences sociales, 144, pp. 7-20.

De Swaan, Abram (1993). "The Emergent World Language System." International Political Science Review, 14, 3, pp. 219-226.

De Swaan, Abram (2001). Words of the World: The Global Language System. Cambridge, Polity Press.

Espagne, Michel and Michael Werner, eds. (1990). Philologiques. Paris, Editions de la Maison des Sciences de l'Homme.

Even-Zohar, Itamar (1990a). "The Position of Translated Literature within the Literary Polysystem.” Poetics Today, 11, 1, pp. 45-52.

Even-Zohar, Itamar (1990b). "Israeli Hebrew Literature." Poetics Today, 
11, 1, pp. 169-170.

Heilbron, Johan (1999). "Towards a Sociology of Translation: Book

Translations as a Cultural World System." European Journal of Social Theory, 2, 4, pp. 429-444.

Heilbron, Johan and Gisèle Sapiro (2002). "La traduction littéraire, un objet sociologique." Actes de la recherche en sciences sociales, 144, pp. 3-5.

Heilbron, Johan and Gisèle Sapiro (2008). "Pour une sociologie de la traduction: bilan et perspectives." In G. Sapiro, ed. Translatio. Le marché de la traduction en France à l'heure de la mondialisation. Paris, CNRS Éditions.

Heinich, Nathalie (1984). "Les traducteurs littéraires: l'art et la profession." Revue française de sociologie, XXV, pp. 264-280.

Kalinowski, Isabelle (2002). "La vocation au travail de traduction." Actes de la recherche en sciences sociales, 144, pp. 47-54.

Prunč, Erich (2007). "Priest, Princes and Pariahs. Constructing the Professional Field of Translation." In M. Wolf and A. Fukari, eds. Constructing a Sociology of Translation. Amsterdam/Philadelphia, John Benjamins, pp. 39-56.

Sapiro, Gisèle (2002). "L'Importation de la littérature hébraïque en France: entre communautarisme et universalisme." Actes de la recherche en sciences sociales, 144, pp. 80-98.

Sapiro, Gisèle (2008a). "Translation and the Field of Publishing. A Commentary on Pierre Bourdieu's 'A Conservative Revolution in Publishing' from a Translation Perspective.” Translation Studies, 1, 2, pp. 154-167.

Sapiro, Gisèle (2008b). "De la construction identitaire à la dénationalisation: les échanges intellectuels entre la France et Israël.” In G. Sapiro, ed. Translatio. Le Marché de la traduction en France à l'beure de la mondialisation. Paris, CNRS Éditions.

Sapiro, Gisèle, ed. (2008c). Translatio. Le Marché de la traduction en France à l'heure de la mondialisation. Paris, CNRS Éditions.

Sapiro, Gisèle (2014). "The Sociology of Translation: A New Research Domain." In C. Porter and S. Bermann, eds. Companion to Translation Studies. New York, Wiley-Blackwell, pp. 82-94.

Sela-Sheffy, Rakefet (2005). "How to Be a (Recognized) Translator: Rethinking Habitus, Norms, and the Field of Translation.” Target, 17, 1, pp. 1-26.

Sela-Sheffy, Rakefet and Miriam Shlesinger, eds. (2011). Identity and Status in the Translational Professions. Amsterdam/Philadelphia, John Benjamins. 
Serry,Hervé,ed.(2001)."Littératures etidentités.”Sociétéscontemporaines, 44.

Simeoni, Daniel (1998). “The Pivotal Status of the Translator's Habitus.” Target, 10, 1, pp.1-39.

Thiesse, Anne-Marie (1991). Écrire la France. Le mouvement régionaliste de langue française entre la Belle Époque et la Libération. Paris, PUF.

Thiesse, Anne-Marie (1998). La Création des identités nationales. Europe $X V I I^{e}$ siècle-XXe siècle. Paris, Seuil.

Toury, Gideon (1995). Descriptive Translation Studies and Beyond. Amsterdam/Philadelphia, John Benjamins.

Venuti, Lawrence (1995). The Translator's Invisibility: A History of Translation. London and New York, Routledge.

Weber Max (1995). Économie et société, t. 1, Paris, Plon, coll. «Pocket».

\section{Gisèle SAPIRO}

École des hautes études en sciences sociales 190-198 avenue de France 75013 Paris FRANCE sapiro@msh-paris.fr 